\title{
Stuttering Rates and Articulation Rates under Choral Reading and White-Noise Reading Relative to Typical Reading
}

\author{
Jin Park', Inkie Chung ${ }^{2}$ \\ 'Division of Human Rehabilitation Services, Catholic Kwandong University, Gangneung, Korea \\ ${ }^{2}$ Department of English, Sogang University, Seoul, Korea
}

\author{
일반읽기상황과 비교한 합독상황과 백색소음상황에서 말더듬 비율과 조음속도 \\ 박 진 $\cdot$ 정 인 기 ${ }^{2}$ \\ 가톨릭관동대학교 휴먼재활서비스학부 ${ }^{1}$, 서강대학교 영미어문전공²
}

\begin{abstract}
Purpose: This study aims primarily to examine whether there are significant differences in stuttering rates and articulation rates among the following three reading conditions: typical reading (i.e., no provision of external auditory stimulus), choral reading (i.e., provision of another speaker's same speech signal) and white-noise reading (i.e., provision of white-noise as a type of mechanical noise). Methods: Nine (9) male adults who stutter have participated in the study and been asked to read a series of passages of 405 syllables (consisting of 897 phones) on average in length. Stuttering rates have been computed based on a percentage of syllables stuttered (\%SS) and articulation rates have been assessed in syllables uttered per second and in phones uttered per second. Results: Results show that there is no significant difference in stuttering rates among the three experimental reading conditions. With respect to articulation rates, no significant difference is found among the three experimental conditions in terms of syllables uttered per second. A significant difference, however, is found in articulation rates computed on a basis of phones uttered per second: Tests of post hoc comparisons reveal a significant difference between typical reading and choral reading. The Spearman tests for non-parametric correlation show no significant correlation between stuttering rate and articulation rate. Conclusion: The findings suggest that the fluency enhancement of adults who stutter attained under the choral reading and white-noise reading condition is not associated with a reduction in articulation rates.
\end{abstract}

Key Words: Stuttering rate, Articulation rate, Choral reading, White-noise reading, Fluency enhancing condition.

\section{INTRODUCTION}

말더듬은 대표적인 말유창성 장애로서 주로 말소리, 음절, 단 어 등이 비정상적으로 반복되거나 연장이나 막힘과 같은 비운 율적 발성으로 말의 산출이나 흐름이 원활하지 않게 되는 장애 이다(Van Riper, 1982; Wingate, 1970). 이러한 말더듬 치료에 는 주로 반복, 연장, 막힘 등과 같은 핵심 행동 소거를 목적으로 말속도 줄이기, 부드럽게 시작하기, 긴장 풀고 발음하기 등과 같 은 유창성 유도기법을 통해 유창하게 말하는 법을 가르치는 '유창성 완성법'과 좀 더 진전된 상태의 말더듬는 사람을 대상 으로 더듬는 순간 근육의 긴장을 풀고 이완된 상태에서 힘들
이지 않고 편안하게 더듬는 법을 가르치는 '말더듬 수정법’ 등 이 있다(Lee, 2010). 이 치료법들이 주로 말더듬는 사람이 의식 적으로 자신의 발화를 직접 조절하는 형태로 이루어지는 것이 라면, 이와 달리 다양한 외부 청각자극들을 이용해 유창성을 촉진하는 방법들도 사용된다. 시간적으로 지연된 자신의 말소 리를 들으면서 말하는 지연청각피드백(delayed auditory feedback, DAF), 주파수가 변조된 자신의 말소리를 들으면서 말하 는 주파수변조피드백(frequency-altered feedback, FAF), 다 른 사람의 동일한 발화를 들으면서 말하는 합독, 기계소음의 일종인 백색소음을 들으면서 말하는 백색소음상황 등이 대표 적인 예들이다. 
외부 청각자극을 통한 유창성 증진 효과에 대한 몇몇 주목할 만한 주장을 살펴보면, 첫째는 주의전환 효과(distraction effect) 설명이다. 즉, 외부 청각자극이 말더듬는 사람으로 하여금 자신 의 발화(말더듬)보다 제공된 외부자극에 더 주목하게 함으로써 일종의 심리적 주의전환 효과를 일으켜 말더듬이 감소하게 된다 는 것이다(Barber, 1939). 그러나 이러한 심리적 기제에 근거한 설 명은 그 개념의 모호성은 물론 실험 증명상의 어려움으로 이미 여러 연구자들의 비판을 받아 왔다(Fransella \& Beech, 1965).

둘째는 외부 청각자극을 통해 제공된 특정 말소리 정보[예, 분절음 정보, 운율 정보, 조음동작(articulatory gestures) 정보] 가 청각적 감시(모니터링) 과정을 통해 말더듬는 사람의 유창한 발화생성에 이용된다는 주장이다(Kalinowski \& Saltuklaroglu, 2003; Kalinowski et al., 2004; Kent, 1984). 예를 들면, Kent (1984)는 말더듬은 말운동과 관련된 시간 정보 인출상의 문제 로 발생하며 합독자극과 같은 외부 청각자극이 시간 관련 정보 를 제공해 줌으로써 말더듬이 감소한다는 주장을 하였다. 또한 Kalinowski \& Saltuklaroglu(2003)는 외부 청각자극이 분절음 이나 운율이 아닌 말소리 정보 산출에 관여하는 일련의 조음기 관들의 움직임(동작)을 의미하는 조음동작에 대한 정보를 제 공해 줌으로써 말더듬이 감소한다고 주장하였다. 특히, 이들은 합독상황에서 유창성 증진 효과가 가장 두드러진다는 점에 주 목하면서(Andrews et al., 1982), 외부 합독자극이(읽어야 하는) 목표 발화의 조음동작 정보를 더 많이 포함하고 있을수록(즉, 목표 발화와 유사할수록) 유창성 증진 효과가 커진다고 주장하 였다. 결국 목표 발화와의 유사성(근접성)과 관련해 제공되는 외부 합독자극(의 특성)이 말더듬을 감소시키는 주 요인으로 작 용한다는 것이다. 그러나 Howell과 그의 동료들은(Howell, 1990; Howell et al., 1983; Howell \& Sackin, 2002) 비언어 외 부자극[예, 박자기 소리(metronome click), 시각/촉각을 통한 리듬자극]을 제공한 경우에도 말더듬이 유의하게 감소한다는 점에 주목하면서(Kuniszyk-Jó́kowiak et al., 1996) 목표 발화 와의 유사성에 상관없이 발화의 시간 조절에 영향을 줄 수 있 는 모든 외부자극은 유창성 증진 효과를 일으킬 수 있다고 주 장하였다.

마지막으로는 말속도, 강도, 주파수 등의 변화로 나타나는 말 더듬는 사람의 음성적 변화로 인해 말더듬이 감소한다는 주장 이 있다(Hayden et al., 1982; Wingate, 1970). 백색소음이나 합독자극과 같은 외부 청각자극으로 인해 화자의 발화 강도가 증가한다는 일명 '롬바드 효과(Lombard effect)'와 관련된 설명 이라고 할 수 있다. 그러나 백색소음을 이용한 다수의 연구에서 발화 강도(Martin et al., 1984), 말속도(Macleod et al., 1995), 주 파수(Brayton \& Conture, 1978) 등과 같은 발화와 관련된 변수 상의 변화가 관찰되지 않았음에도 불구하고 말더듬 비율이 유
의하게 감소했다는 점을 고려한다면, 이는 아직까지 충분한 설 득력을 얻지 못한 주장이라고 할 수 있겠다. 따라서 좀 더 다양 하고 더욱 민감하게 음성 변화를 관찰할 수 있는 변수를 통한 연구가 필요하다고 하겠다.

본 연구는 기본적으로 일반읽기상황(외부 청각자극을 제공 하지 않는 상황)과 비교해 합독상황과 백색소음상황에서 말더 듬 성인의 말더듬 비율과 조음속도의 변화, 그리고 두 변수 간 의 상관성 정도를 분석하는 것을 주 목적으로 한다. 조음속도는 전반적 말속도(overall speech rate)와는 달리 발화 내 비유창 성(또는 말더듬), 상대적으로 긴 심 등을 모두 제외하기 때문에 단순히 말의 빠르기를 나타내는 지표를 넘어 말 운동의 시간적 측면 또는 전이 능력을 보여주는 변수라고 할 수 있다(Chon et al., 2012; Lee et al., 2003; Park et al., 2015). 이를 통해 결국 말 산출을 위해 조음기관들이 얼마나 빠른 속도로 움직이는지를 확인해 볼 수 있다. 전반적으로 말속도가 빨라 말을 더듬는 사 람의 말 운동 통제 능력을 넘어서는 경우에는 비유창성이 발생 할 수 있다(Gottwald \& Starkweather, 1999). 이런 이유로 말 속도 감소를 통해 말 산출을 위한 충분한 운동 시간을 확보함 으로써 말더듬을 유의하게 감소시키는 유창성 증진 기법들이 실 제 치료 현장에서 사용되고 있다(Lee, 2010; Tasko et al., 2007). 이런 맥락에서 만약 조음속도가 일반읽기상황과 비교해 합독상 황이나 백색소음상황에서 유의하게 감소한다면 이는 이러한 유 창성 증진 상황에서 발생하는 말더듬 비율의 감소 현상에 대한 하나의 설명적 근거가 될 수 있을 것이다. 본 연구에서는 조음 속도 측정을 위해 일반적으로 사용되고 있는 초당발화음절수 (syllables uttered per second) (Chon et al., 2012; Lee et al., 2003)뿐만 아니라 더욱 민감한 측정법으로 알려진 초당발화분 절음수(phones uttered per second) (Hall et al., 1999; Tumanova et al., 2011)도 측정하여 각 실험 상황 간 차이가 발생하는지 를 알아보고자 한다.

본 연구의 질문들은 다음과 같다. 첫째, 말더듬 성인을 대상 으로 일반읽기상황, 합독상황, 백색소음상황 간 말더듬 비율에 있어 유의한 차이가 나타나는가? 둘째, 말더듬 성인을 대상으 로 일반읽기상황, 합독상황, 백색소음상황 간 조음속도에 있어 유의한 차이가 발생하는가? 이는 다음과 같은 두 가지 세부 질 문으로 나눌 수 있다. 첫째, 음절수를 바탕으로 한 조음속도(초 당발화음절수)에 있어 실험 상황 간 유의한 차이가 발생하는가? 둘째, 분절음수를 바탕으로 한 조음속도(초당발화분절음수)에 있어 유의한 차이가 발생하는가? 마지막으로 말더듬 비율과 각 조음속도 간 유의한 상관관계가 나타나는가? 하는 것이다. 


\section{MATERIALS AND METHODS}

\section{연구 대상}

말더듬 성인 9명(남성 9명, 평균연령 34세, 표준편차 7.42세) 이 실험 대상자로 참여하였다. Table 1은 실험 대상자에 대한 관련 정보를 제공하고 있다.

대상자 선정기준은 18 세 이상의 성인으로 한국어를 모국어로 하며, 정상 시력과 청력을 가지고 있으며, 심리적, 정서적, 신경학 적 병력을 가지고 있지 않으며, 최근 2년 동안 변조청각피드백 (altered auditory feedback, AAF)이나 합독상황에서의 실험 또 는 치료 경험이 없는 대상자이다. 순음청력검사를 실시한 결과, 모두 정상역치 $(250 \mathrm{~Hz}$ 와 $4,000 \mathrm{~Hz}$ 구간에서 $25 \mathrm{~dB}$ 이하)의 청 력을 보였다. 제1저자(유창성 장애 진단 및 치료 경험과 언어재 활사 1급 자격증 소지자)가 파라다이스유창성검사 II(ParadiseFluency-Assessment-II) (Shim et al., 2010)를 통해 실험 대상 자들의 말더듬 정도를 평가하였으며, 검사결과 심함 5 명, 중간 2 명, 약함 2 명의 말더듬으로 진단되었다. 두 명의 대상자가 말 더듬 치료를 받고 있었지만(Table 1: S04, S09), 치료의 시작단 계로서(치료 개시 후 2주 이내) 실험 당시 모두 자신의 말더듬 문제를 심각하게 인지하고 있었다.

\section{연구 절차}

본 실험에 앞서 미리 준비한 질문지를 통해 실험 대상자의 연 령, 성별, 교육 정도와 같은 기본 정보와 시작 시기, 주요 증상, 진전 양상, 가족력 유무 등과 같은 말더듬 관련 사례검사를 실 시하였다. 또한 어휘 이해력과 읽기 능력을 평가하기 위해 수 용-표현어휘력검사의 수용어휘검사(Receptive and Expressive Vocabulary Test-Receptive) (Kim et al., 2009)와 BASA 읽기 검사(Basic Academic Skills Assessment-Reading) (Kim, 2008)의 읽기검사 자료('토끼야 토끼야'와 '분명히 내 동생인데’) 를 이용하였다. 읽기검사는 기본적으로 대상자로 하여금 읽기
검사 자료를 읽게 하여 읽기 오류(예, 빠뜨린 글자, 더 넣은 글 자, 잘못 발음한 글자) 유무를 검사하였으며, 어느 대상자에서 도 읽기 오류가 나타나지 않았다. 이후 대상자에게 실험 내용 에 대한 간략한 설명을 제시한 후, 두 개의 문장(“동해물과 백 두산이 마르고 닪도록 하나님이 보우하사 우리나라 만세”, " $\bigcirc$ $\bigcirc$ 대학교 주소는 $\bigcirc \bigcirc$ 시 $\bigcirc \bigcirc$ 구 $\bigcirc \bigcirc$ 동 $\bigcirc$ 번지이다")을 통한 연습 상황을 제공하여 대상자가 본 실험을 실제로 수행하는 데 용이하도록 하였다.

본 실험은 기본적으로 대상자로 하여금 일반읽기상황, 합독 상황, 그리고 백색소음상황에서 일정량의 구절을 소리 내어 읽 도록 하였다. 평상시에 읽는 속도로 최대한 자연스럽게 읽도록 하였으며, 유창한 발화를 유도하기 위해 사용되는 방법(예, 손 가락 두드리기, 말속도 줄여 말하기, 부드럽게 시작하기)은 사 용하지 않도록 했다. 제공된 읽기 자료는 고등학교 수준으로 평 균 405 음절(범위 393 415)(평균 897 분절음, 범위 893 904) 분 량으로 작성되었다(Appendix). 실험자극은 대상자에 따라 무 작위순으로 제공하였다. 이월 효과를 고려하여 실험 중간에 본 실험의 구절자극 내용과는 상관이 없는 다양한 주제(예, 즐겨 보는 TV 프로그램, 가족, 직장, 여행, 군대, 존경하는 사람)에 대해 3 분 정도 자유롭게 말하도록 하였다. 본 연구는 대학 소재 연구윤리위원회의 승인하에 진행되었으며(서강대학교 IRB No. 2014-37) 실험 전 모든 대상자는 충분한 실험 설명을 바탕으로 서면 동의서를 작성하였다.

\section{청각자극}

본 연구에서 사용된 백색소음과 합독자극은 다음과 같다. 백색소음은 인간의 가청영역 범위 주파수대역인 $20 \mathrm{~Hz}$ 에서 20 $\mathrm{KHz}$ 에 걸쳐 균일한 에너지 분포를 보이는 일종의 기계소음 (Fastl \& Zwicker, 2007; Katz \& Lezynski, 2002)으로 본 연구 에서는 백색소음생성기(TMSOFT: https://www.tmsoft.com) 를 통해 생성되었다. 합독자극은 한국어를 모국어로 사용하는

Table 1. Participants' demographic and test scores information

\begin{tabular}{|c|c|c|c|c|c|c|}
\hline ID\# & Age & Gender & Level of education & $\begin{array}{c}\text { REVT-R } \\
\text { (raw scores) }\end{array}$ & $\begin{array}{l}\text { BASA-Reading } \\
\text { (\# of errors) }\end{array}$ & $\begin{array}{c}\text { Severity of stuttering } \\
\text { (percentiles) }\end{array}$ \\
\hline S01 & 36 & Male & College graduate & 162 & 0 & $81-90 \%$ ile \\
\hline S02 & 28 & Male & Undergraduate & 161 & 0 & $81-90 \%$ ile \\
\hline S03 & 43 & Male & Undergraduate & 157 & 0 & $11-20 \%$ ile \\
\hline S04 & 22 & Male & Undergraduate & 161 & 0 & $51-60 \%$ ile \\
\hline S05 & 36 & Male & College graduate & 159 & 0 & 11-20\%ile \\
\hline S06 & 33 & Male & College graduate & 163 & 0 & $61-70 \%$ ile \\
\hline S07 & 30 & Male & College graduate & 171 & 0 & $81-90 \%$ ile \\
\hline S08 & 44 & Male & High school graduate & 159 & 0 & $81-90 \%$ ile \\
\hline S09 & 19 & Male & Undergraduate & 170 & 0 & $81-90 \%$ ile \\
\hline
\end{tabular}

REVT-R: Receptive and Expressive Vocabulary Test-Receptive, BASA-Reading: Basic Academic Skills Assessment-Reading 


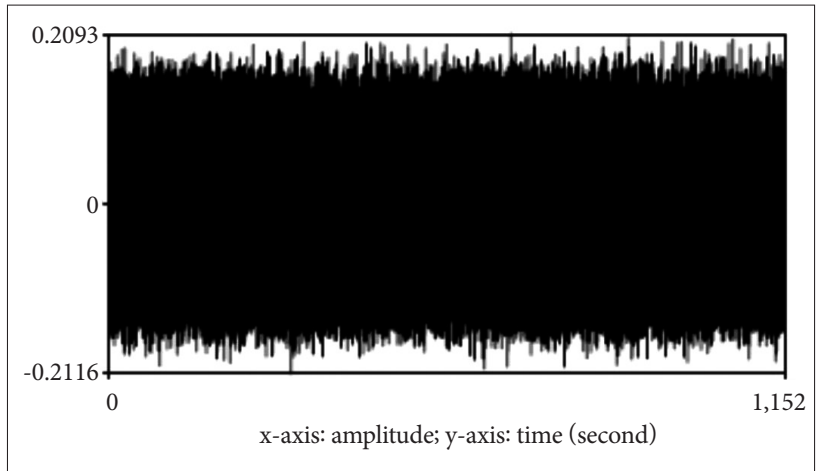

Figure 1. Random waveform of white noise.

성인(남자, 32세)으로 하여금 구절을 읽도록 하여 녹음되었다. 녹음은 방음 처리가 된 대학 소재 음성학실험실에서 실시하였 으며 휴대용 디지털 녹음기(EDIROL R-09, Roland, Los Angeles, CA, USA)가 사용되었다. 합독자극의 평균 말속도는 초 당 4.64음절이다(Roach, 1998). 녹음된 모든 청각자극(백색소 음과 합독자극)은 wave 파일로 변환해 사용하였다. Figure 1은 본 실험에서 실제 사용한 백색소음 표본을 나타낸 파형이다.

\section{실험환경과 장치}

모든 실험은 방음 처리가 되어 있는 대학 소재 음성학실험실 에서 실험 대상자가 컴퓨터(Inspiron 2200, Dell, Hopkinton, $\mathrm{MA}, \mathrm{USA}$ ) 화면에 나오는 일정량의 구절을 소리 내어 읽는 방식 으로 실시되었다. 외부 청각자극(백색소음, 합독자극)은 이어폰 (LifeChat LX-3000, Microsoft, Redmond, WA, USA)을 통해 적 절한 세기(즉, $75 \mathrm{~dB} \mathrm{SPL}$ 이내) (Rami et al., 2005)로 제공하였다. 대상자로부터 약 $20 \mathrm{~cm}$ 떨어진 송화기(SM48, Shure, Chicago, $\mathrm{IL}, \mathrm{USA}$ )를 이용해 대상자의 발화를 수집하였다. 모든 실험 상황 은 디지털카메라(NTSC 2R65MC, Canon, Tokyo, Japan)로 촬 영하였으며 휴대용디지털녹음기(ICD-P320, Sony, Tokyo, Ja$\mathrm{pan})$ 를 사용해 음성을 추가적으로 녹음하였다.

\section{자료 분석 및 통계 처리}

말더듬 비율(\%SS)은 말소리, 음절, 또는 일음절 낱말 반복, 연 장, 막힘과 같은 '진성비유창성(stutter-like disfluency)'의 비율 로 측정하였다. 구체적으로 각 실험 상황에서 관찰되는 진성비 유창성의 총합을 해당 구절의 총 음절수로 나눈 후 100 을 곱해 계산하였다. 음절은 필수적인 요소인 음절핵(모음)과 함께 여러 수의적(optional) 분절음이 결합한 것이다. 각 분절음은 개별 산출과 관련된 조음기관의 움직임(의 속도)에 대한 내재적 시간 정보를 가지고 있다(Browman \& Goldstein, 1989). 따라서 음 절을 바탕으로 한 조음속도 측정으로는 음절보다 더 작은 단위 인 분절음의 산출과 관련된 조음기관의 움직임에 대한 시간적
측면을 측정하고 확인하는 데에는 제한이 있을 수 있다(Hall et al., 1999). 이에, 본 연구에서는 조음속도 측정을 위해 초당 발화음절수(syllables uttered per second)뿐 아니라 초당발화 분절음수(phones uttered per second)도 함께 측정함으로써 실험 상황 간 차이가 발생하는지를 알아보았다. 이를 위해 각 구절의 총 음절수와 총 분절음수를 비유창(말더듬) 구간과 상 대적으로 긴 심(250 ms 이상)을 제외한 전체 발화 구간(초 단위) 으로 나누어 측정하였다(Chon et al., 2004; Hall et al., 1999; Tumanova et al., 2011). 조음속도 분석을 위해 Praat (version 6.0.35: Boersma \& Weenink, 2017)을 사용하였다. 표본 수가 비교적 적은 점을 고려하여 비모수통계법인 프리드만 테스트 (Friedman test), 관련 효과 크기 검증은 켄달의 일치도계수 (Kendall's W test) (Ellis, 2010), 사후 검증으로는 윌콕슨 테스트 (Willcoxon Sign Rank test)를 사용하였다. 또한 스피어만 상관 계수(Spearman correlation coefficient)를 통해 말더듬 비율과 조음속도 간의 상관관계를 분석하였다. 통계 검증을 위해 SPSS (version 21, IBM Corp., Armonk, NY, USA)를 사용하였다.

\section{신뢰도 분석}

3명의 대상자를 무작위로 선정해 일반읽기상황과 백색소음 상황에서의 각각 말더듬 비율과 조음속도에 대한 연구자 내와 연구자 간 일치 정도를 분석하였다. 연구자 간 일치 정도 분석 을 위해 본 실험 내용과 목적을 인지하고 있지 않으며 1 급 언어 재활사 자격증 소지자로 수 년간의 임상경험을 가지고 있는 유 창성 장애 전문가가 참여하였다. 검사결과, 말더듬 비율에 있어 연구자 내( $\mathrm{r}=0.951, p<0.001)$, 연구자 간 $(\mathrm{r}=0.932, p<$ 0.001) 모두 상대적으로 높은 신뢰도를 보였다. 조음속도에 있어 서도 초당발화음절수는 연구자 내 $(\mathrm{r}=0.941, p<0.001)$, 연구자 간 $(\mathrm{r}=0.927, p<0.001)$, 초당발화분절음수는 연구자 내 $(\mathrm{r}=$ $0.937, p<0.001)$, 연구자 간(r $=0.935, p<0.001)$ 모두 높은 신뢰도를 보였다.

\section{RESULTS}

\section{실험 상황 간 말더듬 비율의 차이}

프리드만 테스트 결과, 각 실험 상황 간 유의한 차이를 보이 지 않았다 $\left(\chi^{2}(2)=0.438, p=0.804\right.$, Kendall's $\left.\mathrm{W}=0.024\right)$. 이는 일반 상황과 비교해 합독자극과 백색소음을 제공한 구절읽기 상황에서 유의한 차이가 나타나지 않았음을 보여주는 결과이 다. Table 2 는 각 실험 상황에서의 말더듬 비율과 제 1,3 사분위, Figure 2 는 말더듬 비율의 중위값(제 2 사분위)을 나타낸 것이다. 


\section{실험 상황 간 조음속도의 차이}

프리드만 테스트 결과, 초당발화음절수에서는 실험 상황 간 에 유의한 차이가 나타나지 않은 반면 $\left(\chi^{2}(2)=2.667, p=0.264\right.$, Kendall's $\mathrm{W}=0.148)$ 초당발화분절음수에서는 유의한 차이가 나타났다 $\left(\chi^{2}(2)=6.222, p=0.045\right.$, Kendall's $\left.\mathrm{W}=0.346\right)$. 초당 발화분절음수에 대한 사후 검증 결과, 일반읽기상황과 합독상 황 간에는 유의한 차이가 나타난 반면 $(\mathrm{Z}=-2.192, p=0.028)$ 일반읽기상황과 백색소음상황 간 $(\mathrm{Z}=-1.955, p=0.051)$, 합독 상황과 백색소음상황 간 $(\mathrm{Z}=-1.599, p=0.110)$ 에서는 유의한 차이가 나타나지 않았다. Table 3은 각 실험 상황에서의 조음속 도와 제 1,3 사분위, Figure 3은 조음속도의 중위값(제2사분위) 을 나타낸 것이다.

\section{말더듬 비율과 조음속도 상관관계}

말더듬 비율과 조음속도(초당발화음절수와 초당발화분절음 수) 간 유의한 상관관계를 보이지는 않았다. 그러나 초당발화음

Table 2. Percentages of syllables stuttered (\%SS) across each of the experimental reading conditions

\begin{tabular}{cccc}
\hline & \multicolumn{3}{c}{ Conditions } \\
\cline { 2 - 4 } ID \# & $\begin{array}{c}\text { Typical } \\
\text { reading }\end{array}$ & $\begin{array}{c}\text { Choral } \\
\text { reading }\end{array}$ & $\begin{array}{c}\text { White-noise } \\
\text { reading }\end{array}$ \\
\hline S01 & 3.00 & 0.00 & 3.32 \\
S02 & 8.69 & 0.24 & 2.75 \\
S03 & 0.99 & 0.00 & 0.99 \\
S04 & 0.99 & 0.25 & 0.00 \\
S05 & 0.49 & 0.75 & 0.49 \\
S06 & 0.00 & 0.25 & 0.00 \\
S07 & 8.52 & 4.22 & 5.73 \\
S08 & 0.00 & 0.74 & 0.74 \\
S09 & 0.24 & 0.25 & 0.74 \\
First quartile & 0.12 & 0.12 & 0.25 \\
Third quartile & 5.76 & 0.75 & 3.04 \\
\hline
\end{tabular}

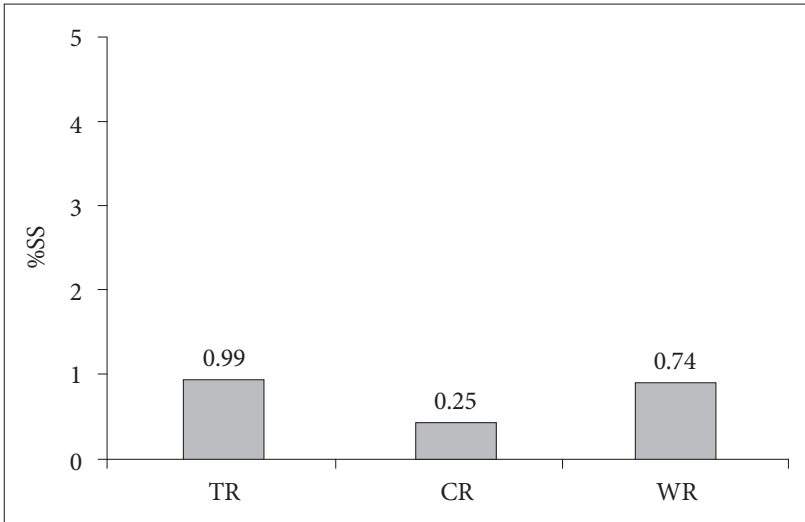

Figure 2. Stuttering rates (median scores) across each of the experimental conditions. TR: typical reading, CR: choral reading, WR: white noise reading. \%SS: percentage of syllables stuttered.
절수 $(\mathrm{rho}=-0.264, p=0.183)$ 에 비해 초당발화분절음수(rho = $-0.311, p=0.114$ )에서는 다소 높은 부적 상관관계가 나타났다. Table 4는 각 실험 조건에서의 말더듬 비율과 조음속도 간의 상 관관계 결과를 제공한다.

Table 3. Articulation rates across each of the experimental conditions

\begin{tabular}{|c|c|c|c|c|c|c|}
\hline \multirow{3}{*}{ ID \# } & \multicolumn{6}{|c|}{ Conditions } \\
\hline & \multicolumn{2}{|c|}{$\begin{array}{l}\text { Typical } \\
\text { reading }\end{array}$} & \multicolumn{2}{|c|}{$\begin{array}{l}\text { Choral } \\
\text { reading }\end{array}$} & \multicolumn{2}{|c|}{$\begin{array}{c}\text { White-noise } \\
\text { reading }\end{array}$} \\
\hline & sps & pps & sps & pps & sps & pps \\
\hline S01 & 4.74 & 10.27 & 5.51 & 12.45 & 5.05 & 11.86 \\
\hline S02 & 4.56 & 10.76 & 5.70 & 12.54 & 5.31 & 11.49 \\
\hline S03 & 5.55 & 12.14 & 5.77 & 13.58 & 5.45 & 11.78 \\
\hline S04 & 6.46 & 13.98 & 5.71 & 13.47 & 7.14 & 15.28 \\
\hline S05 & 5.32 & 11.35 & 5.91 & 12.89 & 5.44 & 12.29 \\
\hline S06 & 5.32 & 11.52 & 6.23 & 14.41 & 6.71 & 13.99 \\
\hline S07 & 5.62 & 11.89 & 6.40 & 14.23 & 6.35 & 13.02 \\
\hline S08 & 5.31 & 11.13 & 4.72 & 10.93 & 5.30 & 10.65 \\
\hline S09 & 6.60 & 13.76 & 6.16 & 14.23 & 6.83 & 13.71 \\
\hline First quartile & 4.96 & 11.13 & 5.62 & 12.54 & 5.31 & 11.78 \\
\hline Third quartile & 6.45 & 12.14 & 6.27 & 14.23 & 6.62 & 13.71 \\
\hline
\end{tabular}

sps: syllables uttered per second, pps: phones uttered per second

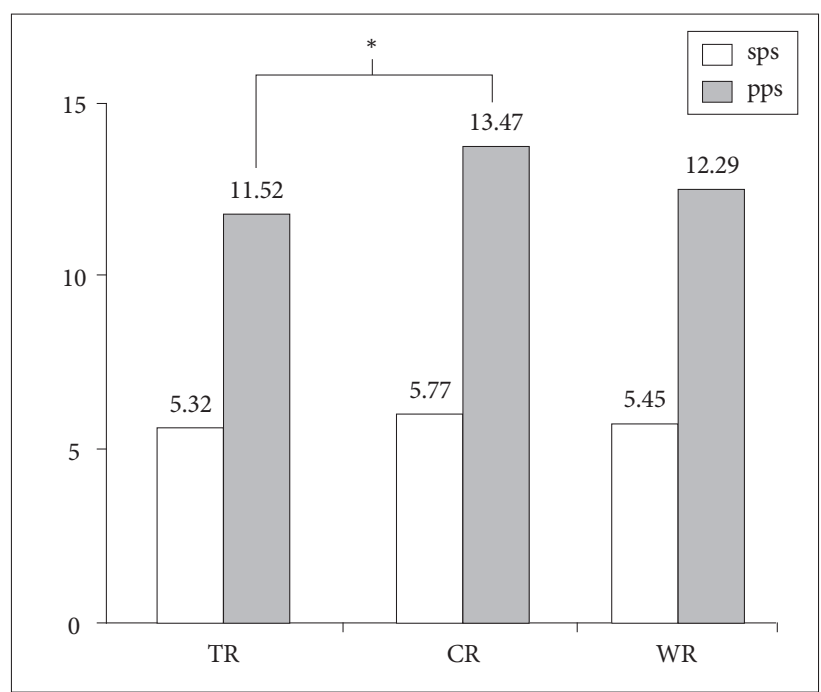

Figure 3. Articulation rates (median scores) across each of the experimental conditions. *Significant difference at the level of 0.05 . TR: typical reading, CR: choral reading, WR: white-noise reading, sps: syllables uttered per second, pps: phones uttered per second.

Table 4. Correlations between stuttering rates and articulation rates for each of the three experimental conditions

\begin{tabular}{lccc}
\hline \multirow{2}{*}{ Conditions } & \multirow{2}{*}{ Variables } & \multicolumn{2}{c}{ Articulation rates } \\
\cline { 3 - 4 } Typical reading & Stuttering & $-0.277(p=0.470)$ & $-0.202(p=0.603)$ \\
Choral reading & rates & $0.434(p=0.243)$ & $0.171(p=0.660)$ \\
White-noise & & $-0.521(p=0.150)-0.513(p=0.158)$
\end{tabular}
reading sps: syllables uttered per second, pps: phones uttered per second 


\section{DISCUSSIONS}

먼저 본 연구의 결과를 요약해 본다면 다음과 같다. 첫째, 일 반읽기상황, 합독상황, 그리고 백색소음상황 간 말더듬 비율에 있어 유의한 차이가 나타나지 않았다. 둘째, 조음속도에 있어 초당발화음절수에서는 실험 상황 간 유의한 차이가 나타나지 않은 반면, 초당발화분절음수에서는 유의한 차이가 나타났다. 사후 검증 결과, 일반읽기상황에 비해 합독상황에서 초당발화 분절음수가 유의하게 증가하였다. 마지막으로 말더듬 비율과 조음속도에서 유의한 상관관계가 나타나지 않았다.

위의 결과를 바탕으로 몇몇 사항에 대하여 논의하자면 첫째, 본 연구에서는 일반읽기상황과 비교해 합독상황이나 백색소음 상황과 같은 유창성 증진 상황에서의 말더듬 비율에 있어 유의 한 차이가 발생하지 않았다. 이는 이전 연구들(Andrews et al., 1982; Ingham et al., 2009)과는 상이한 결과이다. 비교적 적은 수 의 대상자 $(\mathrm{n}=9$ 명 $)$, 자발화 상황과 비교해 읽기상황에서 말더듬 비율이 현저히 낮아진다는 점(Bloodstein, 1995) 등과 관련해 설 명될 수 있다. 그러나 일반읽기상황과 비교해 $(\mathrm{M}=0.99)$ 상대 적으로 낮은 합독상황과 백색소음상황의 중위 수 $(\mathrm{M}=0.25$, $\mathrm{M}=0.74)$ 를 고려할 때 이러한 유창성 증진 경향성은 충분히 관찰해 볼 수 있다고 할 것이다. 읽기상황에서 말더듬이 유의하 게 감소하는 현상에 대해서는 일반적으로 자발화 산출 과정에서 필수적인 의도된 메시지 생성, 단어 생성 및 관련 문법 또는 음 운 정보 인출 등과 같은 언어 형식화 단계(linguistic formulation) 가 생략될 수 있기 때문이다(Bloodstein \& Ratner, 2008). 그러 나 읽기 문단의 의미적, 문법적, 음운적 복잡성에 따라 또는 읽 기 상황과 관련된 개인의 부정적 경험의 유무에 따라 동일한 읽 기 상황이라도 말더듬 비율에 있어 다양한 개인차가 존재할 수 있다(Bloodstein, 1995). 따라서 향후 연구에서는 자발화뿐 아니 라 읽기상황에서도 일정 비율 이상(예, $3 \%$ 이상)의 말더듬을 보 이는 대상자만을 선정해 연구를 진행하거나 분석에 포함시킬 필요가 있다고 하겠다.

둘째, 조음속도에 있어서 초당발화음절수에서는 실험 상황 간에 유의한 차이가 나타나지 않았다. 이는 일반읽기상황과 비 교해 합독상황과 백색소음상황에서 말더듬 대상자의 조음속 도에 유의한 변화가 나타나지 않았음을 보여주는 것이다. 다시 말해, 실험 상황과 무관하게 비교적 유사한 수준의 조음속도 로 발화가 이루어졌음을 의미한다. 반면, 초당발화분절음수에 있어서 일반읽기상황에 비해 합독상황에서 변화, 즉 유의한 수 준만큼의 조음속도 증가가 관찰되었다. 이는 서론에서 언급한 것처럼 유창성 증진 책략으로서 조음속도 감소가 나타나지 않 았음을 보여주는 결과이다. 요컨대, 초당발화음절수에 있어서 세 실험 상황 간의 유의미한 차이가 나타나지 않은 점과 초당
발화분절음수에서 일반읽기상황과 비교해 합독상황에서 조음 속도가 증가하였다는 것은 결국 이러한 유창성 증진 상황에서 나타나는 말더듬 감소가 조음속도 감소(느린 조음속도)와는 상 관성이 없음을 보여주는 것이다. 또한 합독상황과 비교해 일반 읽기상황에서 상대적으로 느린 조음속도를 보인 결과에 대해서 는 말더듬이 말 산출 과정상 관련 언어나 음운 정보 인출상의 시간적 지연으로 추가 시간이 요구되어 결국 조음속도가 감소하 게 된다는 이론적 설명(Perkins et al., 1991; Postma \& Kolk, 1993)의 타당성을 보여주는 예시라고 할 수 있다.

셋째, 몇몇 연구(Hall et al., 1999; Tumanova et al., 2011)에 서 초당발화음절수와 초당발화분절음수를 통한 조음속도 측 정에서 상반되는 결과를 보이고 있다. 즉, 초당발화음절수에는 말더듬 대상자와 일반 화자 간에 유의미한 차이를 보이지 않는 반면 초당발화분절음수에 있어서는 그룹 간에 유의미한 차이 를 보인다는 것이다. 위에서 언급한 것처럼, 음절은 기본적으로 여러 분절음의 결합 체계로서 각각의 분절음은 산출과 관련된 조음기관의 움직임에 대한 내재적 시간 정보를 가지고 있다 (Browman \& Goldstein, 1989). 따라서 단순히 음절을 바탕으 로 한 조음속도 측정으로는 더 작은 발화 단위로서의 분절음 산 출과 관련된 조음기관의 시간적 측면을 측정하고 확인하는 데 제한이 있을 수밖에 없다(Hall et al., 1999). 물론 개별 분절음 을 모두 파악하고 산정하는 데 상대적으로 많은 시간적 소요와 노력이 요구되겠지만, 그럼에도 불구하고 더욱 민감한 측정법으 로서 초당발화분절음수에 근거한 조음속도 측정법의 타당성을 인지하여 향후 관련 연구나 임상 분야에서 더욱 보편적으로 사 용되기를 기대해 본다.

마지막으로, 본 연구에서는 합독상황이나 백색소음상황에서 말더듬 감소 현상이 말더듬 대상자의 음성적 변화, 즉 느린 조 음속도와는 연관이 없음을 보여주고 있다. 이는 이러한 유창성 증대 상황에서 말더듬 감소가 말속도, 강도, 주파수와 같은 말더 듬 대상자의 음성적 변화와는 유의미한 연관성이 없다는 주장 (Hayden et al., 1982; Wingate, 1970)에 힘을 실어주는 하나의 실험적 사례가 될 수 있다. 이에 대해 하나의 설명적 대안으로 제공되는 외부자극의 유형이 말더듬 빈도의 변화를 초래하는 주 요 요인이라는 주장이 있을 수 있다(Kalinowski \& Saltuklaroglu, 2003; Kalinowski et al., 2004; Kent, 1984). 그러나 단순히 언어자극(예, 합독자극)뿐만 아니라 비언어자극[예, 백색소음, 박자기 소리(metronome click), 시각/촉각을 통한 리듬 자극]이 제공되는 상황과, 더 나아가 외부자극이 제공되지 않은 상황(예, 말속도 줄여 말하기, 음절 단위로 말하기) 등에서도 공히 유창성 증대 효과가 나타나는 현상을 인지하면, 이에 대해 더욱 통합적 이고 보편적인 이론적 설명 기제가 요구된다고 할 것이다.

본 연구는 몇 가지 측면에서 한계점을 가지고 있다. 첫째, 상 
대적으로 적은 수의 대상자로 인해 통계상의 검정력(power) 문 제가 있을 수 있겠기에, 실험 결과의 해석과 일반화에 신중을 기해야 하겠다. 구체적으로는 각 실험 상황에서의 말더듬 비율 과 조음속도의 변화, 특히 분절음을 바탕으로 한 조음속도(초 당발화분절음수)에 대한 결과 해석에 주의를 기울일 필요가 있 겠다. 따라서 향후의 연구는 충분한 수의 대상자를 대상으로 실시되어야 하겠다. 둘째는 상당수의 대상자들이 일반읽기상 황에서 비교적 적은 비율의 말더듬을 보인 점이다. 이로 인해 합독상황과 백색소음상황과 같은 일반적으로 알려진 유창성 증진 상황에서 말더듬 비율의 감소가 유의하게 나타나지 않은 결과를 보였다. 사실 이러한 점을 주지하여 본 연구에서는 비교 적 말더듬 중증도가 높은 대상자들을 모집하여 실험을 실행하 였다. 그럼에도 불구하고 심한 정도의 말더듬을 보인 대상자들 (특히, Table 1: S08과 S09)도 자발화 상황에서는 거의 모든 단 어에서 말더듬을 보이는 반면, 일반읽기상황에서는 거의 말더 듬을 보이지 않았다. 따라서, 향후 연구에서는 일반읽기상황에 서의 말더듬 비율의 다양한 개인차를 인지하여 일정 비율 이상 (예, $3 \%$ 이상)의 말더듬을 보이는 대상자만을 모집하거나 통계 분석에 포함시켜 연구를 실시할 필요가 있다고 하겠다. 셋째, 본 연구에서는 합독상황과 백색소음상황만을 대상으로 연구 를 실행하였다. 향후에는 이 두 상황뿐 아니라 지연청각피드백 (DAF)이나 주파수변조피드백(FAF)과 같은 변조청각피드백 (AAF)을 실험 상황에 포함하여 연구를 실시하여야 하겠다. 이 를 통해 조음속도, 특히 분절음을 바탕으로 한 조음속도에 있 어서 일반읽기상황과 비교하여 어떤 변화가 발생하는지를 알 아볼 필요가 있겠다. 넷째, 합독상황이나 백색소음상황과 같은 유창성 증진 상황에 대한 신경학적 기제와 관련된 설명이 요구 되며, 향후에 이와 관련해 다양한 연구가 실시될 필요가 있겠다. 이는 말더듬이 단순한 말과 관련된 말초근육이나 말초신경계의 문제를 넘어 중추신경계, 즉 뇌의 구조적 또는 기능적 문제로 인 한 것이라는 주장(Connally et al., 2014; Fox et al., 1996)에 근 거해 합독상황이나 백색소음상황에서의 유창성 증진과 관련된 더욱 근원적인 설명이 요구되기 때문이라고 할 것이다.

중심 단어 : 말더듬 비율·조음속도·합독상황·백색소음상황 · 유창성 증진 상황.

\section{Acknowledgments}

본 연구에 도움을 준 9명의 말더듬 성인들과 서강대학교 영미어문 전공 학생 이수환 군에게 감사를 드립니다.

\section{REFERENCES}

Andrews, G., Howie, P. M., Dozsa, M., \& Guitar, B. E. (1982). Stuttering: speech pattern characteristics under fluency-inducing conditions. Journal of Speech and Hearing Research, 25(2), 208-216.
Barber, V. (1939). Studies in the psychology of stuttering: XV. Chorus reading as a distraction in stuttering. Journal of Speech and Hearing Disorders, 4, 371-383.

Bloodstein, O. (1995). A Handbook on Stuttering. (5th ed.). London: Singular Publishing Ltd.

Bloodstein, O. \& Ratner, B. N. (2008). A Handbook of Stuttering. (6th ed.). Clifton Park, NY: Thomson Delmar Learning.

Brayton, E. R. \& Conture, E. G. (1978). Effects of noise and rhythmic stimulation on the speech of stutterers. Journal of Speech and Hearing Research, 21(2), 285-294.

Browman, C. P. \& Goldstein, L. (1989). Articulatory gestures as phonological units. Phonology, 6(2), 201-251.

Cherry, E. C., Sayers, B. M., \& Marland, P. M. (1955). Experiments on the complete suppression of stammering. Nature, 176(4488), 874-875.

Chon, H. C., Ko, D. H., \& Shin, M. J. (2004). Disfluency characteristic and speech rate of stuttering and nonstuttering. Communication Sciences and Disorders, 9(2), 102-115.

Chon, H., Sawyer, J., \& Ambrose, N. G. (2012). Differences of articulation rate and utterance length in fluent and disfluent utterances of preschool children who stutter. Journal of Communication Disorders, 45(6), 455467.

Connally, E. L., Ward, D., Howell, P., \& Watkins, K. E. (2014). Disrupted white matter in language and motor tracts in developmental stuttering. Brain and Language, 131, 25-35.

Ellis, P. D. (2010). The Essential Guide to Effect Sizes: Statistical Power, MetaAnalysis, and the Interpretation of Research Results. Cambridge: Cambridge University Press.

Fastl, H. \& Zwicker, E. (2007). Information processing in the auditory system. In Fastl, H. \& Zwicker, E. (3rd ed.) Psychoacoustics: Facts and Models (pp. 61-110). Berlin: Springer.

Fox, P. T., Ingham, R. J., Ingham, J. C., Hirsch, T. B., Downs, J. H., Martin, C., et al. (1996). A PET study of the neural systems of stuttering. Nature, 382(6587), 158-161.

Fransella, F. \& Beech, H. R. (1965). An experimental analysis of the effect of rhythm on the speech of stutterers. Behaviour Research Therapy, 3(3), 195-201.

Gottwald, S. R. \& Starkweather, C. W. (1999). Stuttering prevention and early intervention: A multi-process approach. In Onslow, M. \& Packman A. The Handbook of Early Stuttering Intervention (pp. 53-82). San Diego, CA: Singular Publishing Company.

Hall, K. D., Amir, O., \& Yairi, E. (1999). A longitudinal investigation of speaking rate in preschool children who stutter. Journal of Speech, Language, and Hearing Research, 42(6), 1367-1377.

Hayden, P. A., Jordahl, N., \& Adams, M. R. (1982). Stutterers' voice initiation times during conditions of novel stimulation. Journal of Fluency Disorders, 7(1), 1-7.

Howell, P. (1990). Changes in voice level caused by several forms of altered feedback in fluent speakers and stutterers. Language and Speech, 33(4), 325-338.

Howell, P., Powell, D. J., \& Kahn, I. (1983). Amplitude contour of the delayed signal and interference in delayed auditory feedback tasks. Journal of Experimental Psychology: Human Perception and Performance, 9(5), 772-784.

Howell, P. \& Sackin, S. (2002). Timing interference to speech in altered listening conditions. The Journal of the Acoustical Society of America, 111(6), 2842-2852.

Ingham, R. J., Bothe, A. K., Jang, E., Yates, L., Cotton, J., \& Seybold, I. (2009). Measurement of speech effort during fluency-inducing conditions in adults who do and do not stutter. Journal of Speech, Language, and Hearing Research, 52(5), 1286-1301.

Kalinowski, J. \& Saltuklaroglu, T. (2003). Choral speech: the amelioration of stuttering via imitation and the mirror neuronal system. Neuroscience and Biobehavioral Reviews, 27(4), 339-347.

Kalinowski, J., Saltuklaroglu, T., Guntupalli, V., \& Stuart, A. (2004). Gestural recovery and the role of forward and reversed syllabic repetitions 
as stuttering inhibitors in adults. Neuroscience Letters, 363(2), 144-149.

Katz, J. \& Lezynski, J. (2002). Clinical masking. In Katz, J (5th ed.) Handbook of Clinical Audiology (pp. 124-141). Philadelphia, PA: Lippincott Williams \& Wilkins.

Kent, R. D. (1984). Stuttering as a temporal programming disorder. In R. F. Curlee \& W. H. Perkins. Nature and Treatment of Stuttering: New Directions (pp. 283-301). San Diego, CA: College-Hill Press.

Kim, D. I. (2008). Basic Academic Skills Assessment: Reading. Seoul: Hakjisa.

Kim, Y. T., Hong, G. H., Kim, K. H., Jang, H. S., \& Lee, J. Y. (2009). Receptive and Expressive Vocabulary Test (REVT). Seoul: Seoul Community Rehabilitation Center.

Kuniszyk-Jóźkowiak, W., Smołka, E., \& Adamczyk, B. (1996). Effect of acoustical, visual and tactile echo on speech fluency of stutterers. Folia Phoniatrica et Logopaedica, 48(4), 193-200.

Lee, K. J., Shin, J. C., Kim, H. H., \& Shim, H. S. (2003). The effects of changes of speech rate on the frequency of stutters in pre-school stuttering children. Communication Sciences and Disorders, 8(3), 134-148.

Lee, S. W. (2010). Fluency Disorders. (6th ed). Seoul: Sigma Press.

Macleod, J., Kalinowski, J., Stuart, A., \& Armson, J. (1995). Effect of single and combined altered auditory feedback on stuttering frequency at two speech rates. Journal of Communication Disorders, 28(3), 217-218.

Martin, R., Haroldson, S. K., \& Triden, K. A. (1984). Stuttering and speech naturalness. Journal of Speech and Hearing Research, 49, 53-58.

Park, J., Oh, S. Y., Jun, J. P., \& Kang, J. S. (2015). Effects of background noises on speech-related variables of adults who stutter. Phonetics and Speech Sciences, 7(1), 27-37.
Perkins, W. H., Kent, R. D., \& Curlee, R. F. (1991). A theory of neuropsycholinguistic function in stuttering. Journal of Speech and Hearing Research, 34(4), 734-752.

Postma, A. \& Kolk, H. H. J. (1993). The covert repair hypothesis: prearticulatory repair processes in normal and stuttered disfluencies. Journal of Speech and Hearing Research, 36(3), 472-487.

Rami, M. K., Kalinowski, J., Rastatter, M. P., Holbert, D., \& Allen, M. (2005). Choral reading with filtered speech: effect on stuttering. Perceptual and Motor Skills, 100(2), 421-431.

Roach, P. (1998). Some languages are spoken more quickly than others. In Bauer, L. \& Trudgill P. Language Myths (pp. 150-158). London: Penguin Books.

Shim, H. S., Shin, M. J., \& Lee, E. J. (2010). Paradise Fluency Assessment II (P-FA-II). Seoul: Paradise Welfare Foundation.

Tasko, S. M., McClean, M. D., \& Runyan, C. M. (2007). Speech motor correlates of treatment-related changes in stuttering severity and speech naturalness. Journal of Communication Disorders, 40(1), 42-65.

Tumanova, V., Zebrowski, P. M., Throneburg, R. N., \& Kulak Kayikci, M. E. (2011). Articulation rate and its relationship to disfluency type, duration, and temperament in preschool children who stutter. Journal of Communication Disorders, 44(1), 116-129.

Van Riper, C. (1982). The Nature of Stuttering (2nd ed.). Englewood Cliffs, NJ: Prentice-Hall.

Wingate, M. E. (1970). Effect on stuttering of changes in audition. Journal of Speech and Hearing Research, 13(4), 861-873. 


\section{APPENDIX}

\section{읽기 자료}

\section{일반읽기 구절(405 음절, 897 분절음)}

우리나라의 가을은 참으로 아름답다. 사계절이 뚜렷한 아름다운 금수강산 그 아름다움의 정점은 가을인 듯하다. 무엇보다도 산에 오를 땐, 더욱더 그 빼어난 아름다움이 느껴진다. 쓰다듬어진 듯한 완만함과 깎아놓은 듯한 뾰족함이 어우러진 산등성이를 따라 오 르다 보면 절로 감탄을 금할 수가 없게 된다. 붉은색, 푸른색, 노란색 등의 여러 가지 색깔들이 어우러져 타는 듯한 감동을 주며 나 아가 신비롭기까지 하다. 숲속에 누워서 하늘을 바라보라. 쌍쌍이 짝 지어 있는 듯한 흰 구름, 높고 파란 하늘을 쳐다보고 있노라면, 과연 옛부터 가을을 천고마비의 계절이라 일컫는 이유를 알게 될 것 같다. 가을에는 또한 오곡백과 등 먹거리가 풍성하기 때문에 결 실의 계절이라고도 한다. 햅쌀, 밤, 호두뿐만 아니라 대추, 여러 가지 떡, 크고 작은 과일들을 맛볼 수 있는데, 가을의 대표적인 명절 인 추석에 우리는 이것들을 쌓아놓고 조상님들께 차례를 지내기도 한다. 또한 가을은 독서의 계절이라 하여 책을 읽으며 시시때때 로 명상에 잠기기도 하는데, 독서는 우리에게 마음을 살찌우고 아름답게 하는 힘을 주기 때문이다.

\section{합독 구절(393 음절, 904 분절음)}

안녕하세요. 저는 육십이 넘은 할머니 김덕례라고 합니다. 한글을 배우고 있는 학생입니다. 한글을 배운 지 2년이 넘었는데도 아 직도 어려운 받침이 있는 글자는 다 틀리니 이 노릇을 어쩌면 좋을지 모르겠습니다. 우리 연배들은 세상이 어려울 때 태어나서 못 배우기도 했지만 내가 어렸을 때에는 여자애들이 글자를 배우면 팔자가 세진다고 아버님이 절대 못 배우게 했습니다. 그것이 두고두 고 내 평생에 한이 될 줄을 몰랐습니다. 우리 집 양반도 이제껏 아무 불편 없이 잘 살았으면서 왜 새삼스럽게 그런 걸 배우려고 하 냐며 제가 한글 공부하는 것을 탐탁지 않게 생각했습니다. 그 설움은 아무도 모릅니다. 혹시나 누가 글씨라도 쓰라고 할까 봐 사람 많이 모인 곳은 가지 않았고 은행에 가서 돈 한 번 찾아보지 못했습니다. 한마디로 눈 뜬 장님이었습니다. 어떤 아줌마가 은행에 갈 때마다 일부러 손에 붕대를 감고 가서 다쳐서 글씨를 못 쓰는 것처럼 다른 사람에게 글씨 부탁을 했다는 피눈물 나는 그 애기는 바 로 제 심정과 똑같습니다. 그러나 지금 전 세상 사는 게 재미있고 즐겁고 항상 행복합니다.

\section{백색소음 구절(415 음절, 894 분절음)}

세상이 좁아지고 있다. 비행기가 점점 빨라지면서 세상이 차츰 좁아지는가 싶더니, 이젠 정보 통신 기술의 발달로 지구 전체가 아 예 한 마을이 되었다. 그래서인지 언제부터인가 지구촌이라는 말이 그리 낮설지 않다. 그렇게 많은 이들이 우려하던 세계화가 바야 흐로 우리 눈앞에서 적나라하게 펼쳐지고 있다. 세계는 진정 하나의 거대한 문화권으로 묶이고 말 것인가? 요사이 우리 사회는 터 진 봇물처럼 마구 흘러드는 외래 문명에 정신을 차리지 못할 지경이다. 세계화가 미국이라는 한 나라의 주도 아래 이루어지고 있다. 일본은 얼마 전 영어를 아예 공용어로 채택하는 안을 검토한 바 있다. 문화 인류학자들은 이번 세기가 끝나기 전에 대부분의 언어들 이 이 지구상에서 자취를 감출 것이라고 예측한다. 언어를 잃는다는 것은 곧 그 언어로 세운 문화도 사라진다는 것을 의미한다. 우 리가 그토록 긍지를 갖고 있는 우리말의 운명은 과연 어떻게 될 것인가? 20세기가 막 시작될 무렵, 뉴욕 센트럴파크의 미국 자연사 박물관 앞 계단에서 몇 명의 영국인들이 자못 심각한 토의를 하고 있었다. 미국의 미래를 논의하였다. 